\title{
LOGÍSTICA DE TRANSPORTES E MODERNIZAÇÃO DO TERRITÓRIO: A IMPORTÂNCIA DOS PLANOS VIÁRIOS NACIONAIS PARA A EFETIVAÇÃO GEOESTRATÉGICA DA MESORREGIÃO DO TRIÂNGULO MINEIRO/ALTO PARANAÍBA
}

\author{
Mauricio Aquilante Policarpo \\ Universidade Federal de Uberlândia - UFU \\ Pós-Graduação em Geografia - Instituto de Geografia, MG, Brasil \\ mauricio policarpo@ufu.br \\ Rita de Cássia Martins de Souza \\ Universidade Federal de Uberlândia - UFU \\ Professora Associada - Instituto de Geografia, MG, Brasil \\ ritacmsou@gmail.com
}

\begin{abstract}
RESUMO
Este trabalho tem como objetivo analisar as influências dos Planos Viários Nacionais de 1874 a 1951 na organização geoestratégica da mesorregião do Triângulo Mineiro/Alto Paranaíba, Oeste do Estado de Minas Gerais, uma vez que estes foram fundamentais para a instalação de uma dinâmica territorial com consequências diretas sobre o interior do país, os quais inseriram essa mesorregião em uma condição estratégica de integração. A atenção principal do trabalho centra-se sobre os planos projetados e/ou implementados durante a Primeira República e a Era Vargas, tendo-se como pressuposto que os mesmos se constituíram em aportes fundamentais para o desenho das redes viárias modernas construídas após a década de 1950. Para tanto, o artigo estrutura-se a partir do levantamento e análise dos planos viários do período em evidência. Paralelamente à compreensão do contexto que deu origem a esses planos, analisa-se as estratégias locais adotadas no sentido de criar para a região do Triângulo Mineiro uma dinâmica específica centrada na logística de transportes. A compreensão do processo de instalação dos sistemas viários na região é um ponto chave para compreender o papel da dinâmica instalada no Triângulo Mineiro dentro do projeto do Estado Nacional para a articulação e modernização do território brasileiro.
\end{abstract}

Palavras-chave: Formação territorial. Logística de transportes. Triângulo Mineiro/Alto Paranaíba.

\section{LOGISTICS OF TRANSPORT AND MODERNIZATION OF THE TERRITORY: THE IMPORTANCE OF NATIONAL ROAD PLANS FOR THE GEO-STRATEGIC EFFECTIVENESS OF THE MESOREGION OF THE TRIÂNGULO MINEIRO / ALTO PARANAÍBA}

\begin{abstract}
This project has the purpose to analyze the influences of the National Road Plans from 1874 to 1951 on the geostrategic organization of the mesoregion of the Triângulo Mineiro / Alto Paranaíba, West of the State of Minas Gerais, since these were fundamental for the installation of a territorial dynamics with direct consequences on the interior of the country, which inserted this mesoregion into a strategic integration condition. The main focus of the project has been the plans designed and / or implemented during the First Republic and the Vargas Era, assuming that they were constituted in fundamental contributions to the design of modern road networks built after the decade of 1950 . For this, the article is structured from the survey and analysis of the road plans of the period in evidence. Furthermore, the understanding of the context that gave rise to these plans, we analyze the local strategies adopted in order to create for the region of Triângulo Mineiro a specific dynamic centered on transport logistics. The understanding of the process of installation of road systems in the region is an important point to understand the role of the dynamics installed in the Triângulo Mineiro within the National State project for the articulation and modernization of the Brazilian territory.
\end{abstract}

Keywords: Territorial formation. Transport Logistics. Triângulo Mineiro/Alto Paranaíba. 


\section{INTRODUÇÃO}

Neste trabalho procura-se compreender as estratégias do ordenamento territorial do Estado brasileiro que elucidam a formação desse território por meio da materialização das redes de transportes e sua dinâmica engendrada sob a égide da modernização e expansão do capital.

Dessa forma, analisa-se os principais planos viários propostos entre os anos de 1874 e 1951, procurando identificar na mesorregião do Triângulo Mineiro/Alto Paranaíba, sua articulação com os projetos de integração nacional. Define-se como marco inicial o Plano Ramos de Queiroz, de 1874 - apesar da existência do Plano Rebelo em 1838 - uma vez que os planos traçados e delineados pela Carta do Império do Brasil (1873) passaram a influenciar os projetos que foram traçados durante a República como base cartográfica para o desenvolvimento dos planos viários. Determinou-se como marco final o ano de 1951, pois os Planos elaborados até essa data tornaram-se documentos essenciais na implantação dos grandes projetos viários durante a segunda metade do século XX, sobretudo durante a Ditadura Militar (1964 - 1985).

Nesse sentido, a publicação versa sobre o período de 1874 a 1951, uma vez que é nesse ínterim que há o delineamento de seguidos planos viários os quais constituem-se em elementos basilares para a posterior elaboração dos Planos Viários Nacionais da década de 1960 em diante. Estes últimos têm influência dos projetos aqui analisados com a efetivação do processo de integração nacional, propiciado pela instalação de Brasília e a necessidade de eixos viários promotores de fluxos de pessoas, capitais e serviços ao longo do território. Devese frisar que os dados e as discussões apresentados neste trabalho extrapolam o período de 1874 a 1951, pois geram efeitos posteriores a essa data, sendo essenciais para compreender a condição geoestratégica do Triângulo Mineiro/Alto Paranaíba.

A mesorregião do Triângulo Mineiro/Alto Paranaíba formou-se no entroncamento de nós viários que interligam o território brasileiro e promovem a integração nacional projetada pelo Estado. Tal configuração é verificada a partir da instalação das redes viárias nacionais com a construção de Brasília, dotando essa região de distinto valor geoestratégico e econômico no país.

Em outras palavras, a recuperação e a análise dos Planos do período de 1874 a 1951 é instrumento fundamental para compreender as dinâmicas posteriores com a instalação da rede viária e a reconfiguração da mesorregião em um quadro geoestratégico. A rede rodoviária nacional, ao ser instalada na região a partir de 1958, foi primordial para o desenvolvimento do Triângulo Mineiro, permitindo a articulação entre o Oeste e as principais áreas industrializadas e urbanizadas do país, favorecendo a dinamização econômica, a atração de fluxos e de capitais, bem como o crescimento acelerado de cidades a partir da década de 1970 e com maior grau na década de 1990.

Destarte, a importância desta reflexão conduz à compreensão das redes viárias enquanto elementos da modernização do território e instrumentos para a formação territorial no país. Vale indicar que as redes cumprem um papel basilar para as interações espaciais, sociais e econômicas, à medida que acompanham as novas necessidades colocadas pelo capital e dinamizam a reprodução e expansão capitalista.

\section{PLANOS VIÁRIOS E MODERNIZAÇÃO NO BRASIL}

Os discursos sobre a necessidade da integração e a articulação territorial são documentados desde a Independência, em 1822. Essa necessidade firmou-se como objetivo central do Estado brasileiro enquanto instância primordial durante o século XX. Desta forma, as redes viárias, no caso brasileiro, sempre foram colocadas ideologicamente enquanto agentes primordiais para a construção da unidade territorial do Brasil. Conforme propõe Moraes (2000), o objetivo da integração territorial sustentou-se na lógica da disseminação de "civilização" e, posteriormente, de "modernização" do território expandindo a conquista e a apropriação dos fundos territoriais.

No entendimento desse geógrafo, os fundos territoriais constituem-se como "áreas de reserva" ainda não acionadas pelo modo de produção em vigência. Vale indicar que o autor mostra que isso não significa que não façam parte dos interesses dos agentes hegemônicos do capitalismo; pelo contrário, são porções estratégicas do território para possibilidades futuras da 
ampliação da riqueza. A história da formação territorial brasileira se caracteriza, segundo o autor, por um processo contínuo de conquista, ocupação e valorização capitalista de novas áreas (MORAES, 2000).

Os Planos Nacionais de Viação foram estrategicamente propostos, a partir de 1838 , com o objetivo de criar bases que sustentariam o projeto de integração territorial e a instalação das redes viárias enquanto uma das estruturas principais para permitir a ocupação e integração definitivas do país. As bases da modernização propostas estavam voltadas para a apropriação e transformação dos fundos territoriais, a partir das características espaciais e produtivas concentradas no litoral, atendendo a necessidade dos anseios presentes nos discursos de progresso e de modernização do Brasil.

Consoante a essa discussão, Galvão (1996) argumenta que as preocupações giravam em torno do crescimento barrado pela ausência de um sistema nacional de comunicações, o que impossibilitava a expansão para o Oeste do Brasil. Tais planos apresentados ao Estado poderiam possibilitar a descoberta e o desenvolvimento de novos recursos que continuavam ocultos, bem como iniciar a expansão da agricultura em áreas economicamente ainda não ocupadas, favorecidas por uma política de imigração e de colonização. Para os engenheiros responsáveis por tais planos, somente através do planejamento e da execução de uma rede viária nacional, o Brasil poderia constituir-se como um Estado verdadeiramente unificado. Nesse sentido, as redes de transportes foram rediscutidas enquanto agentes desse processo primordial para a construção da unidade territorial do Brasil.

Torna-se importante considerar as resistências aos planos de integração nacional via sistemas viários modernos, pois, como indica Brandão (2009), a "abertura" e o acesso da região para sua posterior integração nacional indicavam à perda da hegemonia das classes dominantes locais e sua realocação no Bloco Histórico por outras de caráter nacional e internacional. Galvão (1996) discorre nesse sentido, ao mostrar a resistência dessas classes para com os Planos Viários Nacionais.

Durante os primeiros séculos da história econômica do país, muitas estradas sugeridas pelo governo (inclusive o colonial) e pelos vários engenheiros brasileiros não puderam ser construídas por total falta de viabilidade econômica. Ao longo do tempo, porém, e sobretudo após a Independência, a abertura de estradas enfrentou a resistência das elites agrárias brasileiras, pois estas tinham fortes justificativas, de ordem política e econômica, para se oporem à disseminação de vias de comunicação pelos sertões do país. [...] "O grande proprietário tinha horror a estradas, pois elas representavam uma ameaça ao seu poder feudal" (GALVÃO, 1996 p. 188).

Sousa Neto (2012) reforça que não eram os escassos conhecimentos geográficos ou propriamente a inviabilidade econômica que impediam a implementação dos planos viários já propostos no período Imperial, mas, sobretudo, os interesses políticos das classes dominantes das regiões, onde havia uma resistência à modernização e à integração, motivo pelo qual os planos foram retardados ou relegados em seus objetivos.

Contudo, a partir da segunda metade do século XIX, o Brasil integrou-se mais profundamente à economia mundial, sobretudo com a inserção das ferrovias e pela produção agrícola que se modernizava para a época. A inserção da rede ferroviária que compreendia cerca de nove mil quilômetros no fim do Império (GALVÃO, 1996), tornou-se um importante aparato técnico que modernizou as atividades produtivas de algumas regiões. Isso foi possível concomitantemente ao ordenamento técnico e instrumental do território alimentado pelo ideal positivista de ordem, progresso e da modernização da sociedade, da economia e do território brasileiro.

O advento da era ferroviária no Brasil, no final do século XIX, e o reconhecimento dos enormes impactos das ferrovias nas áreas em que foram instaladas, fizeram com que esta modalidade de transporte passasse a receber prioridade dos engenheiros de transporte.

O principal Plano Viário do período, encomendado pelo governo imperial, foi o Plano Ramos de Queiroz de 1874, o qual influenciou diretamente na composição do primeiro Plano de Comissão, em 1890. Segundo Penha (1993), esse plano, juntamente com o Plano Bulhões, 
acabou delineando a formação de dois grandes blocos macrorregionais no Brasil: o Centro-Sul e o Norte-Nordeste, definindo as relações produtivas e densidades demográficas, uma vez que estruturavam o corpo principal para o desenvolvimento dos planos viários que foram projetados a partir de 1930 e os que foram implantados após a Era Vargas. Galvão (1996) indica claramente que o plano viário por meio das ferrovias norteava o processo do projeto de integração e desenvolvimento da economia brasileira, com o objetivo de "franquear os tesouros ocultos no coração do Brasil aos povos de todas as nações do globo; disseminar a civilização pelo interior de nosso país; economizar o tempo gasto em percorrer as distâncias, de harmonia com os altos interesses políticos e estratégicos" (QUEIROZ apud GALVÃO, 1996).

O Plano Queiroz - 1874 (Figura 1), projetado por Ramos de Queiroz, consistia num plano ferroviário com dois grandes eixos que partiriam do litoral para o interior. Segundo Cavalcanti (2011), no eixo Norte/Nordeste, Queiroz propunha sete eixos ferroviários até a altura do médio São Francisco, criando uma verdadeira rede de comunicações interiores no Nordeste - sendo este o corpo inicial do projeto da ferrovia Transnordestina, em construção atualmente. Já no Centro-Sul do país, define-se o Tronco Sul, estratégico para linhas de interiorização, com destaque para a "artéria central" alcançando as fronteiras do extremo Oeste do território brasileiro, a fim de assegurar a soberania da área com inúmeras terras devolutas. Galvão (1996) indica que Queiroz tinha preocupações estratégicas sobre a viabilidade de se construir e manter vias de comunicações, sem a existência de fluxo correspondente de cargas, mas que assegurariam um deslocamento rápido e estratégico sobre o território brasileiro, além de constituírem eixos denominados "civilizatórios".

Figura 1 - Plano Ramos de Queiroz (1874).

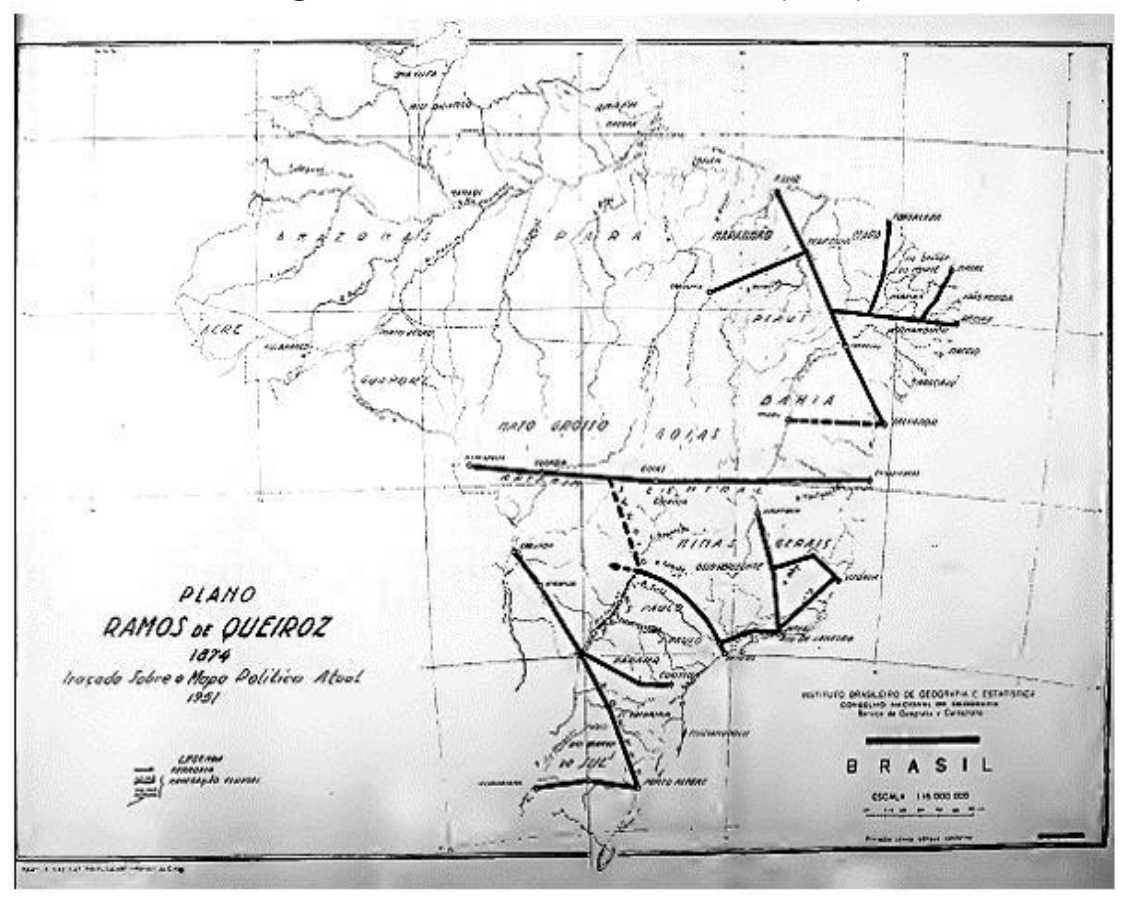

Fonte - Conselho nacional de transportes (1952).

O Plano Queiroz caracteriza-se pela evidente escassez de ferrovias de orientação Norte-Sul. Não delimitava linhas férreas sobre o espaço do Triângulo Mineiro/Alto Paranaíba, mas sua influência está diretamente ligada à idealização dos eixos viários de interiorização, cujo projeto já indicava a necessária "Marcha para o Oeste", recomendando a centralização dos eixos viários para o Planalto Central e as questões estratégicas de ocupação e comunicação ao interior do território.

Apesar de ser fundamental para o delineamento dos planos viários posteriores, o Plano Ramos de Queiroz encontrou sérias dificuldades financeiras. Os planos viários da época não foram implantados, mas permitiram criar discussões sobre a integração do território e favoreceram 
uma base teórica fundamental que se refletiu nos planos viários arquitetados posteriormente na Primeira República (1889 - 1930) e na Era Vargas (1930 - 1945).

\section{OS PLANOS VIÁRIOS DA PRIMEIRA REPÚBLICA: AS PROPOSTAS DE INTEGRAÇÃO}

A partir da instalação da República, em 1889, a discussão da necessidade da integração das zonas mais desenvolvidas e povoadas do litoral ao grande "vazio demográfico" que representava o interior do Brasil, tornou-se mais evidente no Parlamento nacional. No discurso do imperativo da coesão e da articulação territorial destacavam-se: uma visão integracionista, políticas de incentivo à construção de ferrovias e a clara intenção da mudança da Capital Federal para o Planalto Central, já na primeira Constituição Republicana de 1891 (GALVÃO, 1996).

Concomitantemente à instauração da República, em 15 de janeiro de 1890, o Governo Provisório expediu o decreto oㅜ 159, que tratava da organização de um Plano Geral de Viação de caráter federal (Figura 2). O Plano Geral de Viação (Plano de Comissão de 1890) declarava que todas as estradas de ferro fariam parte de um Plano Geral, proposta que orienta a configuração da rede ferroviária brasileira. O relatório da Comissão é um documento histórico que traduz, na elaboração do plano, o pensamento político que o inspirou no sentido da modernização, do progresso e da interiorização das vias e da expansão futura (COIMBRA, 1974). Respeitando as características naturais, sobretudo as grandes bacias hidrográficas, e os aspectos econômicos regionais, traçaram-se as linhas de expansão da rede ferroviária e sua integração à navegação fluvial, dando ao plano proposto um sentido mais executável que os anteriores. Foi esse Plano de Comissão de 1890 que serviu de base à extensão da rede ferroviária que se materializou sobre o território brasileiro.

Figura 2 - Plano de Comissão de 1890.

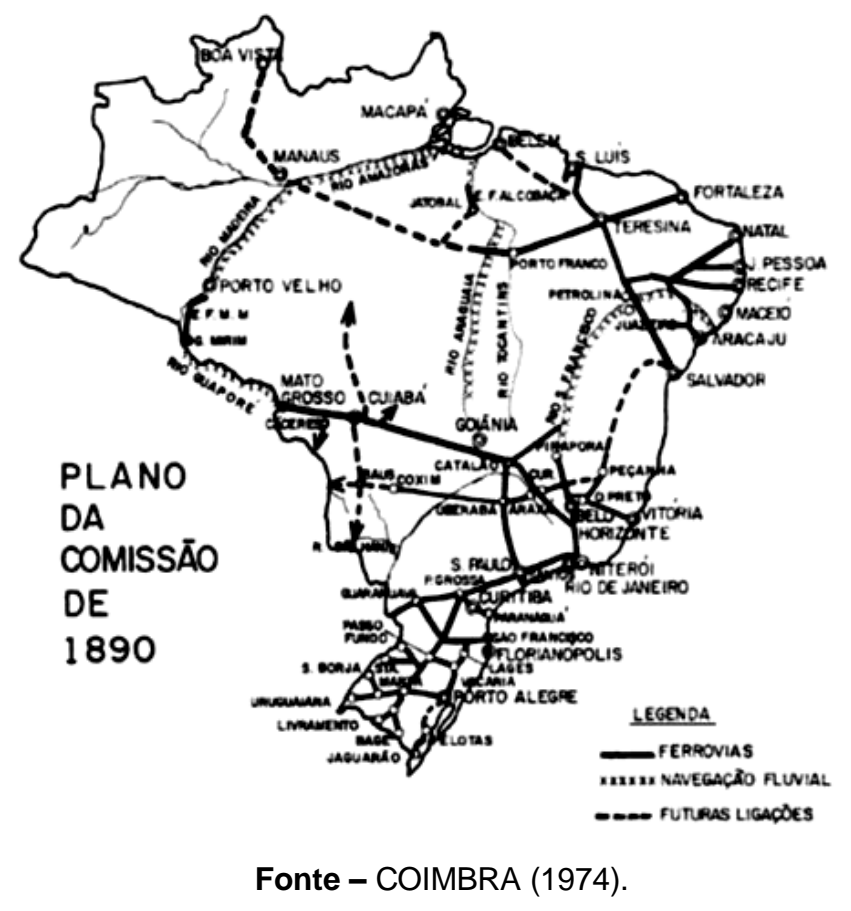

No Plano da Comissão de 1890, o Triângulo Mineiro/Alto Paranaíba aparece com destaque em relação aos outros planos. Concebem-se eixos ferroviários na área, com evidência para Uberaba e Araxá. É interessante notar que o acesso a Uberaba se dá a partir de uma linha tronco que parte de São Paulo e Santos, mostrando a forte conexão dessa área com o desenvolvimento econômico paulista. Além disso, o acesso à futura capital mineira, Belo Horizonte, foi possível através do ramal de Araxá. Dessa forma, nesse plano, Uberaba torna-se um nó entre São Paulo e Belo Horizonte, fruto de sua expressão econômica (pecuária) e 
política durante a confecção do Plano da Comissão. O Triângulo Mineiro aparece, portanto, como uma importante situação geográfica ${ }^{1}$ de integração Norte e Sul e Leste e Oeste, com eixos que convergem em direção a Catalão (Goiás) e de lá, rumam para o Planalto Central. O Plano de Comissão comprova a discussão acerca da necessidade da transferência da capital do país ainda no final do século XIX, bem como seus eixos estratégicos de interiorização a Oeste do território brasileiro.

Em relação as redes viárias, durante a Primeira República houve um aumento significativo do número de ferrovias, sobretudo no Oeste de São Paulo, uma vez que era necessário escoar o café dos seus centros de produção - as fazendas - para o porto de Santos. Além disso, a própria ferrovia era uma infraestrutura indutora da produção cafeeira ao formar espaços produtivos ao longo de seus ramais, contribuindo para estender a fronteira agrícola, como apresentado por Monbeig (1984) ao refletir que a marcha pioneira das ferrovias em direção ao interior paulista representava uma importante força sinérgica que agia na formação da ampliação da produção cafeeira e na constituição de núcleos urbanos.

Desde que tomou pé nos planaltos ocidentais [paulista], prosseguiu a vaga pioneira em sua marcha infatigável, sacudida pelas crises econômicas, acelerada às vezes pelo jogo das circunstâncias políticas mundiais. Incessantemente engrossada por elementos novos, a multidão dos plantadores e dos pioneiros não cessou de progredir, mais ou menos depressa, mas sem fatigar-se. Testemunham avanços sucessivos as cidades, que se sucedem como contas de um rosário, ao longo das ferrovias (MONBEIG, 1984, p. 23).

Outro autor que demonstra como as ferrovias materializadas no interior paulista agia como indutoras da "Marcha para o Oeste" e da expansão do capital é Brandão (2009) ao afirmar que:

A marcha para o Oeste das plantações e das linhas ferroviárias engendrará diversos núcleos urbanos, com destaque para aqueles que cumprirão a função de "bocas do sertão" e de "pontas de linha" [...] a ferrovia contribuiu para estender a fronteira agrícola, criando e ligando, com seu traçado, pontos de produção agropecuária (BRANDÃO, 2009, p. 78).

Nesse sentido, as estradas de ferro se expandiram paulatinamente no interior paulista, a exemplo da Companhia Paulista (1872), comunicando Santos a Jundiaí; da Companhia Ituana (1879), alcançando Piracicaba; da Companhia Sorocabana (1889), ligando a capital paulista a Botucatu e Bauru; e da Companhia Mogiana (1872) - a qual merece maior destaque neste artigo - que partindo de Campinas foi se ampliando até Franca, com um sistema de linha tronco em direção a Minas Gerais, alcançando diretamente o Triângulo Mineiro.

Adentrando Minas Gerais em 1888, após transpassar o Rio Grande, a linha-tronco da Companhia Mogiana atendia as cidades de Sacramento, Conquista e Uberaba, tendo aí chegado em 1889. Já em 1895, a ferrovia se estendeu até Uberabinha, atual Uberlândia, e em 1896, alcançou o ponto final na cidade de Araguari. É importante frisar que a presença da Companhia Mogiana no Triângulo Mineiro tornou as ligações dessa região mineira mais rápidas, fáceis e viáveis com o estado e a cidade de São Paulo do que com a região central do próprio estado mineiro e com a capital Belo Horizonte, fato que foi potencializado no século XX com as rodovias e que permanece até hoje.

Quando considera-se a evolução da malha ferroviária (Figura 3) durante a Primeira República, nota-se que em um período de apenas 20 anos, entre 1905 e 1925, as ferrovias no Brasil dobraram em extensão, representando claramente essa rede viária como um aparato de modernização do território brasileiro.

\footnotetext{
1 Em Silveira (1999) compreende-se o conceito de situação geográfica como um conjunto de relações expressas entre os sistemas técnicos e as ações no lugar. A situação geográfica se torna própria de um valor estratégico ainda mais seletivo em que as vantagens locacionais são potencializadas por seus conteúdos.
} 
Figura 3 - Evolução da rede ferroviária em quilômetros (1890 - 1930).

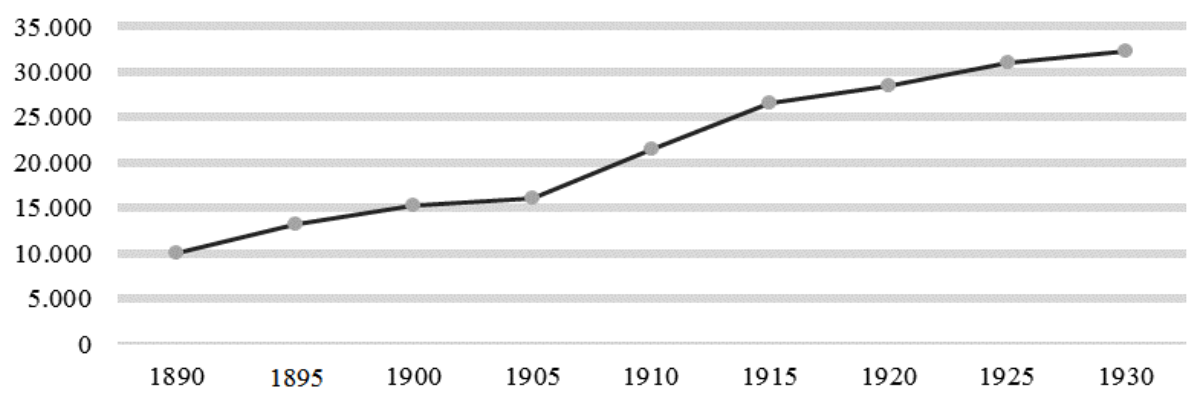

Fonte - SILVA (1976, p. 58). Org - autores, 2017.

No entanto, durante a Primeira República, distintas transformações ocorreram no tecido social e econômico do país, alterando alguns aspectos do Plano da Comissão. Nesse período, entre a Proclamação da República e a "Revolução" de 1930, operam-se na sociedade e na economia brasileira processos significativos que permitirão a criação de bases materiais para a maturação da modernização no país, mostrando sinais claros do processo em curso que a economia exportadora de matérias-primas estava em crise e deveria se industrializar, sobretudo após a Primeira Guerra Mundial (1914 -1918). Essas indústrias, em sua maioria, estavam relacionadas principalmente aos setores de fiação, de tecelagem e de alimentos. Assim, o surgimento desse setor deu bases para a fixação de um incipiente mercado interno substituindo a importação.

Ressalte-se que, ainda que muitas mudanças tenham acontecido na Primeira República, foi a partir de 1930 que elas aconteceram com maior intensidade e maior impacto sobre o território. Não obstante, é válido destacar que a Crise de 1929 contribuiu fortemente para o desmantelamento da economia monocultora da época e a prospecção de um projeto voltado à industrialização e ao desenvolvimento do mercado interno, sendo fundamental o desenvolvimento das redes viárias para o suporte da modernização. Ou seja, as quedas em área colhida e em produção e a dependência da economia brasileira em relação ao café evidenciaram o risco para a economia nacional e as suas limitações, sobretudo com a crise de 1929, tendo na industrialização um aporte significativo para o processo de desenvolvimento e modernização do país. Silveira (2003) sinaliza esse fenômeno ao aferir que:

As quedas, de 1929 a 1945, em área colhida e em produção, representavam um risco para a economia nacional, "pois um país não pode depender da produção de um só produto". A crise, muito evidenciada pelo colapso da bolsa de Nova lorque (1929), estava minando a monocultura cafeeira. A diversificação agrícola e a indústria apareceram como opção, como alternativa mais provável de desenvolvimento econômico (SILVEIRA, 2003, p. 107).

Em outras palavras, o Brasil nas décadas de 1930 e de 1940 sofreu transformações nos planos político, social e econômico e na articulação territorial para a sua modernização, e, consequentemente, na efetivação dos planos viários. É importante destacar que, por trás das iniciativas tomadas subjazia um forte discurso centralizador do Estado.

Como aponta Anselmo e Bray (2002), era necessário consolidar a unidade territorial subordinando as diferentes regiões do país ao Poder Central - fundamental para o desenvolvimento e para o "progresso do país" - para então formar o Brasil moderno, industrial, com mercado consumidor integrado e articulado por infraestruturas viárias. 


\begin{abstract}
Nas décadas de 1930 e 1940, a integração territorial era fundamental para o desenvolvimento - ou para atingir o progresso, para usar terminologia mais de acordo com a época - que, começava a germinar nas mentes de nossas classes dirigentes. A condução da sociedade brasileira, totalmente despreparada para executar a tarefa grandiosa de ascensão do país, somente poderia ser encaminhada pela elite intelectual verdadeiramente conhecedora da realidade nacional. [...] É neste contexto que a expansão territorial, assegurada por uma ocupação controlada pelo Poder Central, através da expansão das vias de comunicação, da instalação da capital política na região central do país, ganha novo ímpeto (ANSELMO; BRAY, 2002, p. 111).
\end{abstract}

Tal fato indicava claramente a necessidade da modernização das estruturas social e política do Brasil, para a edificação da imagem do país a partir da construção de uma nação e a remodelação do Estado. Segundo Machado (2006), alguns intelectuais brasileiros começaram a analisar o território, na procura de compreender o atraso social, econômico e espacial do Brasil e, assim, intervir com proposições a partir de transformações que pudessem ocasionar o desenvolvimento econômico da nação, relacionando-se com o tão ambicionado "progresso". Nesse sentido, os discursos sobre a modernização do país, sustentavam-se sobre concepções a necessidade de expansão da apropriação do território, a identidade nacional, a unidade territorial (diretamente ligadas à ideia de progresso e integração) e a adoção do modelo urbano/industrial.

Para Fonseca (1999), nesse período, o Brasil buscava garantir o mercado para seus produtos, necessitando da articulação e da comunicação territorial, necessários para promover a industrialização e o desenvolvimento capitalista, agora com a maturação do mercado interno.

Sob essa perspectiva, a modernização pela industrialização deveria se concretizar através de um projeto territorial em que, a partir dessa economia mais diversificada e complexa, certas regiões experimentariam a germinação do fenômeno da urbanização e da formação de um mercado interno e a urgência de um modal rodoviário que conduziria a integração do território.

No ano de 1926, durante o governo do presidente Washington Luís, a evidente limitação das ferrovias para o plano de integração nacional devido aos altos custos de implantação de um sistema ferroviário nacional e à desarticulação das ferrovias já implantadas, fizeram com que o Estado adotasse políticas de desenvolvimento rodoviário em nível nacional. Além disso, como trabalhado por Vencovsky (2006), a decadência ferroviária estava atrelada aos eventos decorrentes da crise de 1929, principalmente com as novas necessidades impostas a partir do modelo industrial que preconizava a unificação e integração do mercado nacional em detrimento de um cenário ferroviário constituído por uma malha desarticulada, formada por linhas praticamente independentes entre si e com uma grande disparidade de bitolas. Para este autor haveria dificuldades para manter o modal ferroviário já que, "o processo de industrialização, que requeria sistemas de transportes para a integração do mercado interno, não podia ser atendido pelo sistema ferroviário vigente" (VENCOVSKY, 2006 p. 21). Em contrapartida, a construção das rodovias era mais rápida e barata, atendendo a necessidade urgente de integração do território e ligando a rede urbana/industrial aos produtores e consumidores de forma mais eficiente e articulando os mercados.

Assim, a construção rodoviária passou a ser uma prioridade na confecção dos planos viários para o território brasileiro. No mesmo ano, o IV Congresso Nacional aprovou o plano proposto pelo engenheiro Joaquim Catramby, cujo plano (Plano Catramby-1926) defendia a adoção de um sistema rodoviário, estruturado em dois níveis: um federal e outro estadual, apresentando uma rede rodoviária articulada ao sistema nacional. Uma característica importante do Plano Catramby (Figura 4) é que ele consistia na execução de uma rede rodoviária composta por 29 rodovias, em geral superpostas aos traçados ferroviários, sendo 17 estradas tronco (federais) e 12 linhas de união dos estados, com cortes latitudinais e longitudinais (CAVALCANTI, 2011). 
Figura 4 - Plano Catramby (1926) - rodoviário.

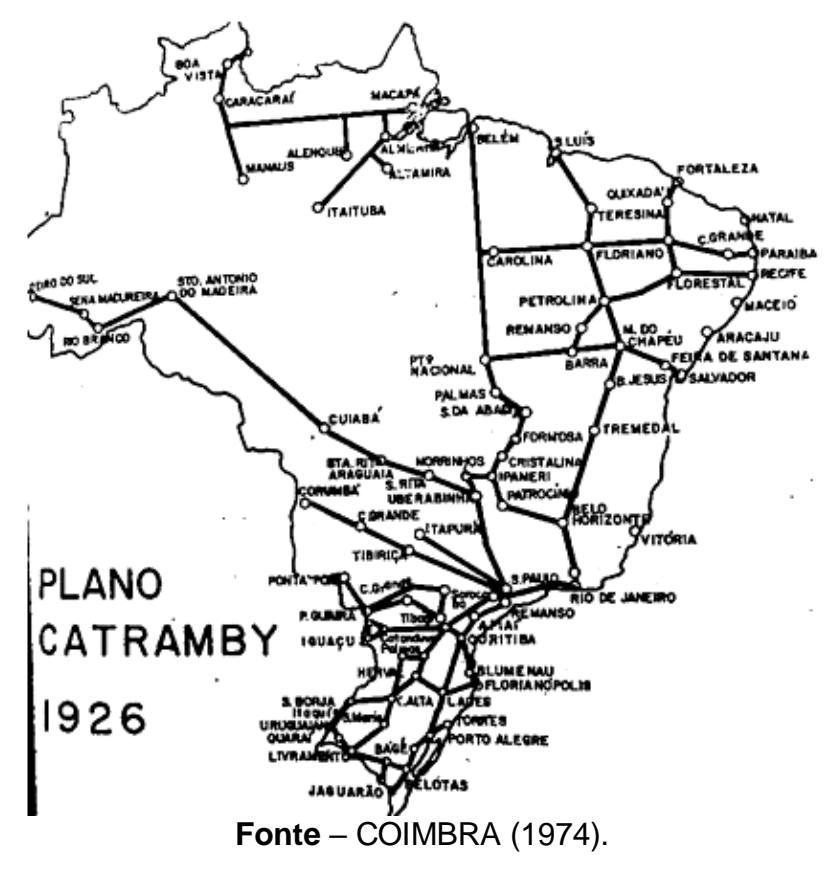

O Triângulo Mineiro/Alto Paranaíba é abordado diretamente no Plano Catramby. Nesse plano viário, Uberabinha (Uberlândia) é um nó viário a partir do eixo rodoviário que parte de São Paulo, atinge Uberabinha e ruma em direção a Morrinhos (pelo Norte até chegar a Santarém no estado do Pará) e o de Santa Rita (Oeste que alcança Cruzeiro do Sul, no Acre). Basicamente, esse eixo rodoviário desenhado no Triângulo Mineiro e em São Paulo é o modelo inicial da Via Anhanguera - no Estado de São Paulo - e da BR 050 em Minas Gerais, cujo traçado é sobreposto diretamente ao do ramal ferroviário da Companhia Mogiana.

Vale salientar que a escolha de Uberabinha e não de Uberaba se deve à Ponte Afonso Pena, em Itumbiara-GO, construída em 1906 pelo Governo Federal, transpassando a barreira do leito do rio Paranaíba e colocando em contato direto o Triângulo Mineiro com o Sudeste e o Sudoeste Goiano. A partir disso, a estratégia e o projeto da elite local uberlandense foi construir e ligar por pavimentos mais modernos essa ponte com a estação ferroviária de Uberlândia, no ano de 1913, cuja infraestrutura privada tornou Uberlândia um nó de rede basilar para a mesorregião e o interior do país. Esse fato deu importância a Uberabinha no Plano de Joaquim Catramby, pois permitiu à cidade ocupar uma posição de logística privilegiada como uma área de influência por todo o Sudoeste e Sudeste Goiano, no Triângulo Mineiro e no Norte Paulista (GUIMARÃES, 2010).

A ligação com a capital mineira fazia-se pelo eixo rodoviário que parte de Patrocínio, atinge Belo Horizonte e chega ao Rio de Janeiro. A presença do ramal ferroviário que liga Patrocínio ao Rio de Janeiro revela a proximidade do Alto Paranaíba (então Julgado de Araxá) com a região central de Minas e com o Rio de Janeiro, à época.

Em 1927, foi apresentado ao Estado brasileiro o Plano Schnoor, confeccionado pelo engenheiro Luiz Schnoor. Esse plano teve por base a localização da futura capital do país no Planalto Central. Schnoor idealizou um sistema rodoviário que irradiava do estado de Goiás para as demais regiões do país, marcando uma forte influência das discussões da transferência da Capital Federal, a fim de propiciar o processo de integração das regiões a partir do centro geográfico do país (COIMBRA, 1974). Dessa forma, o Plano Schnoor-1927 (Figura 5) redesenhou a rede rodoviária a partir de eixos horizontais e verticais. Nesse plano, o Triângulo Mineiro é projetado através de Uberaba, conectada pela rodovia que parte do Planalto Central, e ruma para São Paulo e Santos, conferindo destaque a uma posição privilegiada. Nota-se que não há eixos rodoviários nesse sistema que liguem diretamente Belo Horizonte ao Triângulo 
Mineiro, pois a importância da mesorregião estava ligada diretamente a economia paulista como local de abastecimento agropecuário.

Figura 5 - Plano Schnoor (1927) - rodoviário.

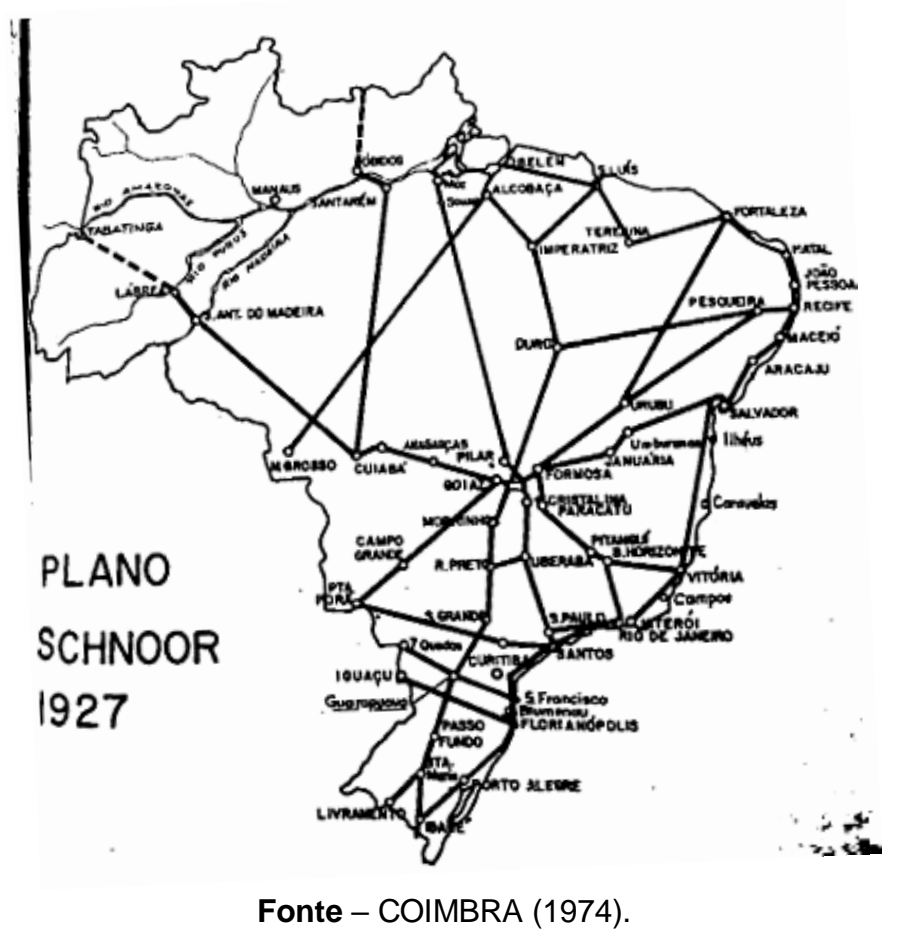

Segundo Santos (2008), os Plano Nacionais de Viação da Primeira República, sobretudo os da década de 1920, compuseram idealizações e planificações que foram fundamentais ao posterior desenvolvimento da questão viária e da integração nacional na década de 1930 . No que se refere ao desenho do traçado, pode-se notar a preocupação com a conexão dos grandes centros urbanos aos núcleos interioranos, apontando a necessidade já posta de um plano de ocupação do interior que se concretizou na República Nova com a "Marcha para $o$ Oeste".

\section{OS PLANOS VIÁRIOS DA ERA VARGAS: O PLANEJAMENTO PARA A ARTICULAÇÃO DO TERRITÓRIO PELAS RODOVIAS E A FORMAÇÃO DO MERCADO INTERNO}

No período que se segue à Revolução de 1930, diversos planos viários pautados na comunicação e na articulação territorial foram propostos, sobretudo por órgãos criados pelo Estado, adquirindo o caráter oficial de execução dos eixos viários a partir de estudos e propostas ligados à coesão e à integração nacional, com destaque ao Instituto Brasileiro de Geografia e Estatística (IBGE). Os planos viários do período assumem caráter extremamente estratégico baseados na soberania nacional para a efetivação da "Marcha para o Oeste", proposta por Getúlio Vargas.

Um dos fatores que propiciaram a expansão dos transportes no final da década de 1930, foi o estabelecimento das metas de colonização interna, a "Marcha para o Oeste". Dentre as medidas relativas a esta campanha, salienta-se a elaboração do Plano Rodoviário Nacional e sua reorganização em 1945 através do Departamento Nacional de Estradas de Rodagem. (PENHA, 1993, pag. 112). 
Seguidos planos viários foram propostos nesse período, como o Plano Geral de Viação Nacional de 1934, o Plano Rodoviário do Departamento Nacional de Estradas e Rodagem, de 1937, o Plano Rodoviário Nacional de 1944 e o Plano Nacional de Viação de 1951. Tais planos deram base para a confecção dos planos viários efetivados sobre o território brasileiro a partir do final da década de 1950 .

O Plano Geral de Viação Nacional de 1934 foi estabelecido pelo Decreto oㅜ 24.497, de 29 de junho de 1934, pelo presidente Getúlio Vargas. Este plano foi realizado por uma comissão de engenheiros ligados ao Governo Federal, sendo o primeiro plano aprovado e oficializado no país. O objetivo da comissão consistia em traçar o plano geral das vias de comunicação de caráter nacional, baseando-se nas contribuições daqueles desenvolvidos anteriormente. Assim, o Plano Geral de Viação Nacional - 1934 (Figura 6) estabelecia a construção de novos troncos e ligações com as materialidades de transportes já existentes formando uma rede viária mais integrada por meio de 18 troncos viários e 18 ligações, sendo 31 terrestres, 4 terrestres fluviais e 3 fluviais. A natureza do plano, priorizava a atender aos seguintes requisitos: ligar a Capital Federal a uma ou mais capitais dos diferentes Estados; ligar qualquer via de comunicação da rede federal a qualquer ponto da fronteira com os países vizinhos; constituir vias de transporte ao longo da fronteira, ou dessa paralela a menos de $200 \mathrm{~km}$ de distância; ligar entre si dois ou mais troncos de interesse geral, com o objetivo de estabelecer, por caminho mais curto, comunicações entre duas ou mais unidades da federação; e, atender a exigências de ordem militar (MINISTÉRIO DOS TRANSPORTES, 2014).

Figura 6 - Plano Geral de Viação Nacional (1934).

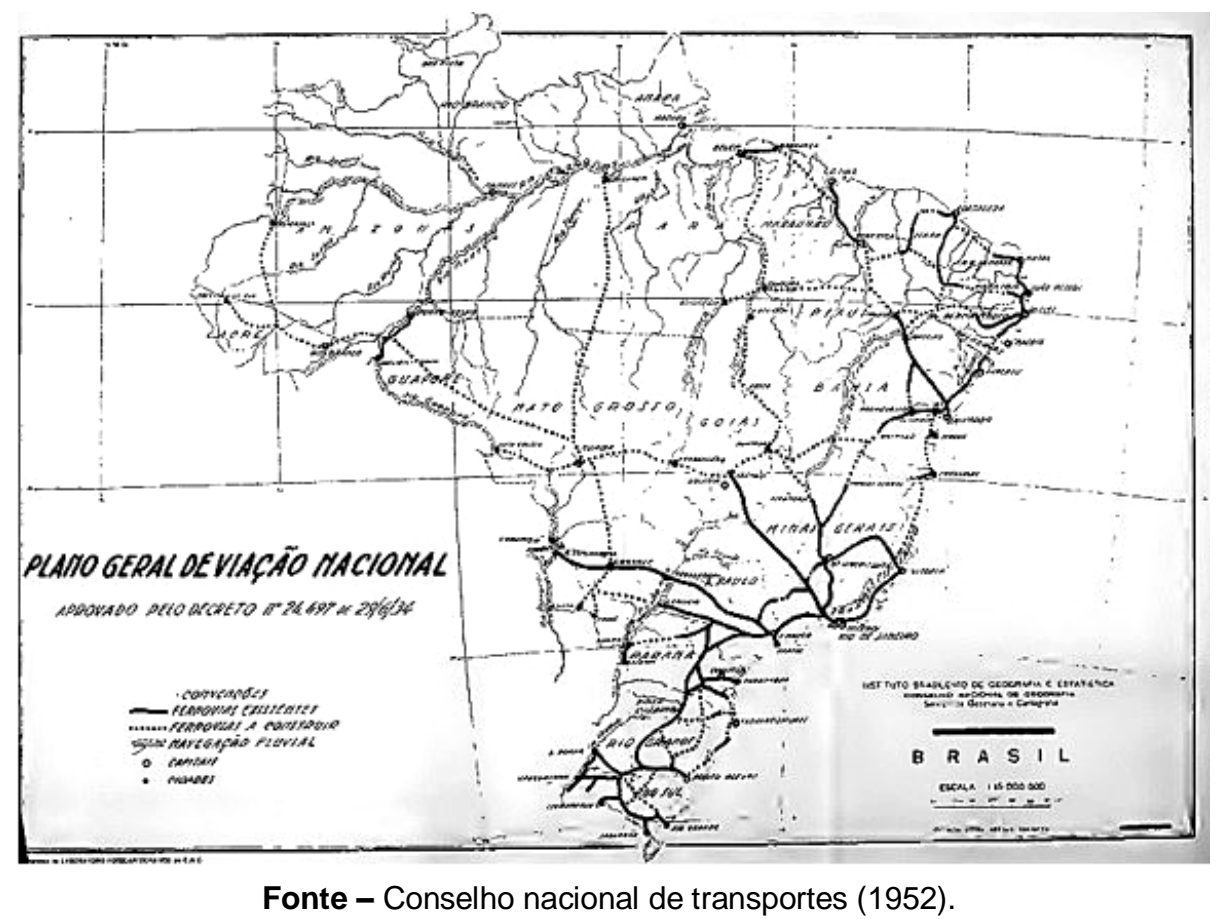

O Plano Geral de Viação-1934 estabelecia um eixo rodoviário importante que atravessaria a região do Alto Paranaíba. Esse eixo partia da capital federal (Rio de Janeiro) e rumava para o Sul de Minas Gerais, na região de Lavras, passava pelo Alto Paranaíba e se estenderia ao Norte da cidade de Goiânia. Esse é um eixo viário fundamental que ligaria diretamente o litoral ao Planalto Central. Desse ponto seriam construídos eixos de integração que, com a transferência da capital federal, efetivariam a unidade territorial, tornando o Alto Paranaíba caso fosse implantado - uma área de integração entre esses dois pontos por meio do eixo rodoviário. 
Três anos mais tarde, em 1937, com o aumento expressivo da frota nacional de automóveis, sobretudo de caminhões, foi necessária a criação de um órgão ligado ao Ministério de Viação e Obras Públicas para planejar e gerenciar os sistemas rodoviários. Dessa forma, o Estado brasileiro, durante o Governo de Getúlio Vargas, criou o Departamento Nacional de Estradas de Rodagem (DNER), nesse mesmo ano, órgão originado da Comissão de Estradas de Rodagem Federais fundada em 1927 pelo Governo Federal e extinta em 1931. Já em 1937, o DNER apresentou um Plano de Viação DNER (Figura 7), acentuando a política rodoviária em detrimento dos demais meios de transporte. O Plano estabelecia um maior número de nós viários e um traçado mais voltado para o interior diante da estratégia da transferência da capital, cuja influência direta deriva do Plano Schnoor-1927.

Figura 7 - Plano Geral DNER - 1937 - rodoviário.

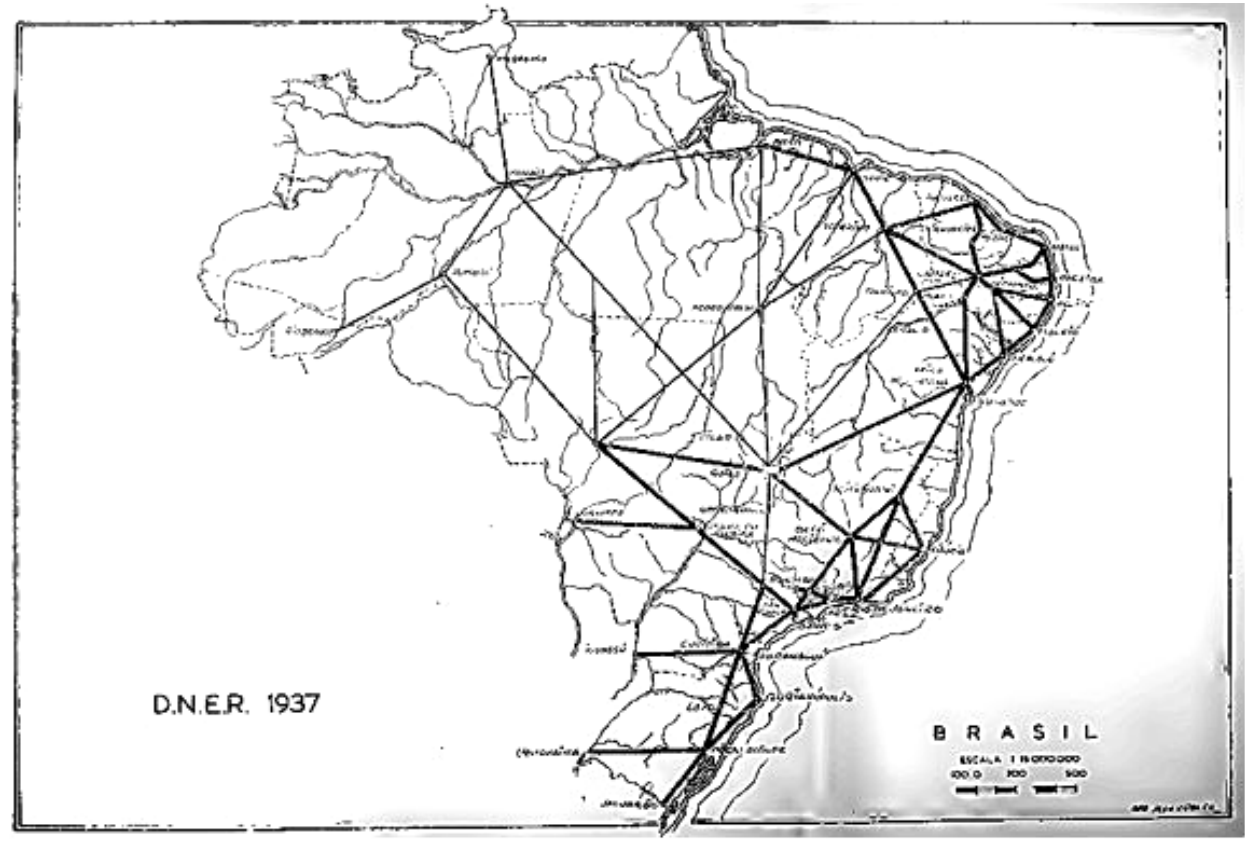

Fonte - Conselho nacional de transportes (1952).

Os condicionantes geográficos e geopolíticos são evidentes no Plano do DNER-1937, sobressaindo-se questões como a da proteção das fronteiras através da implantação dessa infraestrutura viária, da soberania nacional e da unidade territorial com a estratégica centralização dos eixos viários integrados ao Planalto Central e as demais regiões do Brasil por meio de eixos geométricos e longitudinais.

É nesse contexto geoestratégico que o Triângulo Mineiro, particularmente Uberlândia, apresenta destaque no Plano do DNER-1937, conferindo uma situação geográfica de integração entre o interior e os centros econômicos industriais do país. A região é contemplada com uma das principais rodovias longitudinais projetadas (via interior e via litoral), que a conecta ao Sul e ao Norte do Brasil: liga-a por um eixo viário que chega a São Paulo ao Sul; liga-a ao Norte por um eixo que passa por Uberaba e Uberlândia e segue para o Norte atingindo o Planalto Central (Goiânia e Brasília) até Belém; e, conecta-a com Manaus e as capitais do Nordeste. Esse eixo rodoviário longitudinal de enorme importância para a articulação e para a unidade nacional, ao atravessar o Triângulo Mineiro, favorece o segmento de transporte logístico já instalado em Uberlândia, potencializando a acumulação de capital na região pela maior integração ao mercado interno brasileiro.

Já em 1944, foi efetivado o Plano Rodoviário Nacional-1944 (Figura 08), através do Decreto no 15.093, de 20 de março de 1944, que objetivava conectar o país de Norte a Sul e ligá-lo a outras direções (Leste e Oeste). 
Figura 8 - Plano Rodoviário Nacional (1944).

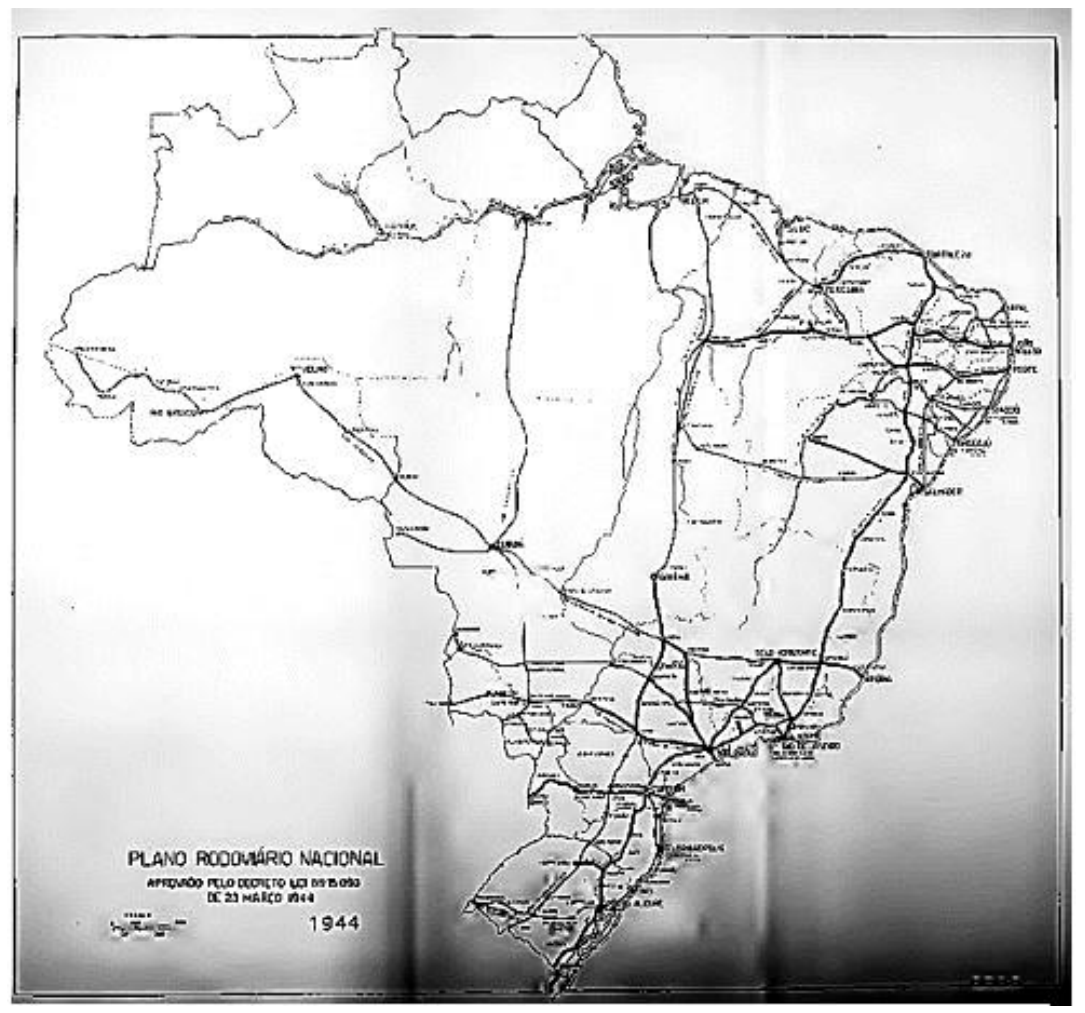

Fonte - Conselho nacional de transportes (1952).

O Plano Rodoviário Nacional - 1944 possibilitou, a partir de sua adoção, a evolução da rede rodoviária brasileira, o qual previa seis rodovias longitudinais, quinze transversais e seis ligações, totalizando, na época, $35.574 \mathrm{~km}$. Segundo o Ministério dos Transportes (2014), 0 Plano Rodoviário Nacional-1944 estabelecia as seguintes diretrizes: a) evitar a superposição das rodovias com os troncos ferroviários principais; b) aproveitar trechos de rodovias existentes ou em projeto dos planos estaduais; c) considerar apenas trechos rodoviários de caráter nacional; e, d) estabelecer, no interior do país, as convenientes ligações da rede rodoviária nacional com a infraestrutura aérea.

Em relação ao Triângulo Mineiro/Alto Paranaíba, o Plano Rodoviário Nacional de 1944 estabeleceu três eixos rodoviários que passariam pela região e a integrariam ao restante do Brasil. Verifica-se que a densidade das redes na mesorregião era significativa, o que atraia significativos investimentos para a área.

Em 1946, a Comissão liderada pelo engenheiro e ministro de Viação e Obras Públicas Maurício Joppert, foi responsável por fazer a revisão das diretrizes expostas pelo Plano de Viação-1934. Segundo Santos (2008), Maurício Joppert definia em sua revisão a "ineficiência" das estradas de ferro frente às outras tecnologias no sentido da integração de regiões remotas, enfatizando a comunicação e suas possibilidades através do advento do rádio e da aviação. Entre esses eixos estratégicos estavam a atual BR 116 (trecho sul concluído em 1956 e trecho nordeste em 1963), a Rodovia Presidente Dutra (1951), Rio de Janeiro - Belo Horizonte (1958) e a Via Anchieta (1944), sendo esta última considerada a primeira autoestrada nacional (SANTOS, 2008).

O Plano de Viação - 1934 realizado pelo Ministro Maurício Joppert, em 1946, foi transformado no Plano Nacional de Viação - 1951, que normatizaria o papel dos sistemas ferroviários no projeto do país e reafirmaria a prioridade dos sistemas rodoviários sobre qualquer outra modalidade, separando o Plano Nacional Rodoviário e o Plano Nacional Ferroviário. Segundo Santos (2008), o Plano Viário - 1951 (Figura 09) mostrava que a adoção de paralelismos entre dois modos distintos de redes viárias poderia garantir uma verdadeira e eficiente rede nacional de transportes. 
Figura 9 - Plano Nacional de Viação - Rodoviário e Ferroviário (1951).

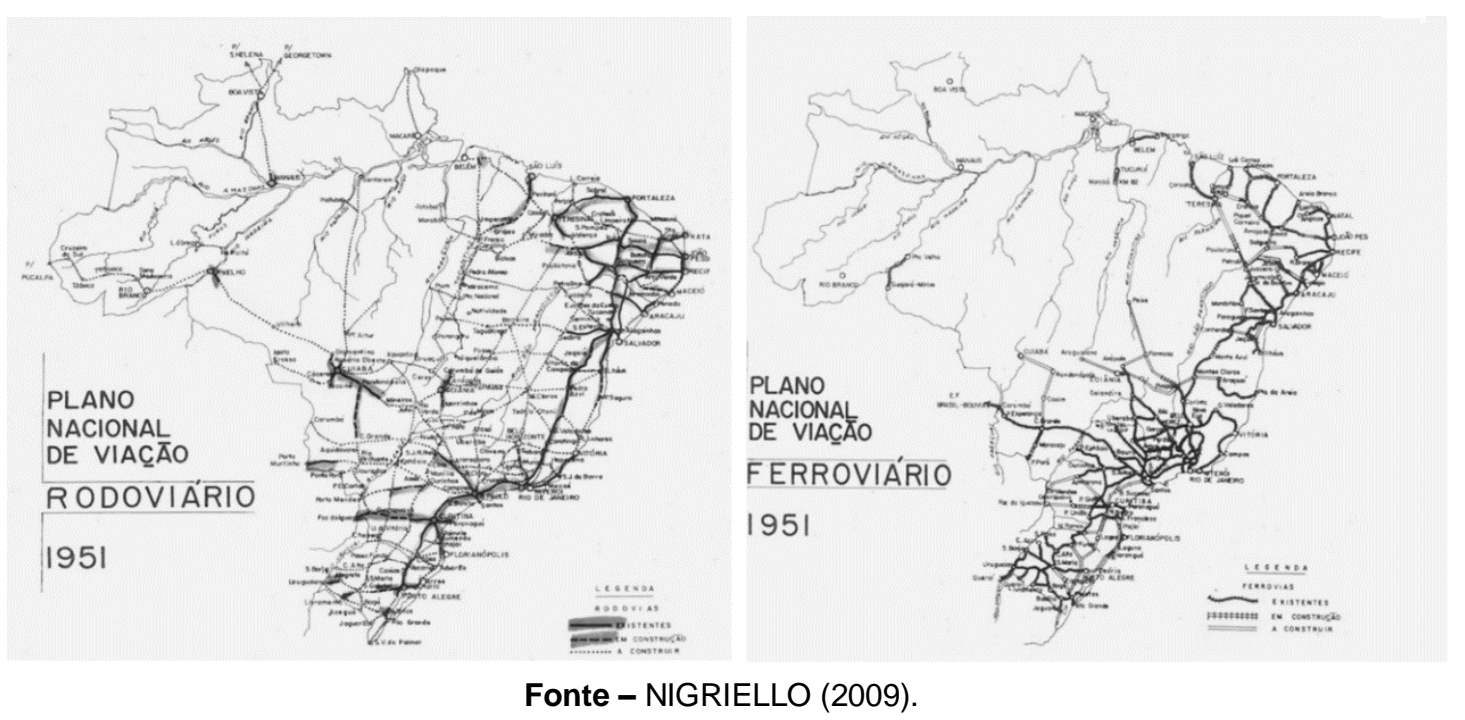

Em verdade, o caráter de intermodalidade perdeu potencialidade à medida em que foram elaborados três diferentes planos para os três modais (ferrovia, rodovia, hidrovia) com elevado grau de independência entre eles. Desse modo, a lógica daquele momento era racionalizar sua implementação e buscar viabilizar os investimentos para as rodovias, propondo um sistema rodoviário federal de 61 mil quilômetros de extensão, com cinco eixos radiais, nove eixos longitudinais e 23 eixos transversais e 42 ligações, recortando o território brasileiro e articulando as regiões do país. O meio de transportes rodoviário foi apresentado como o mais viável para a rápida integração do território segundo as possibilidades da época e as necessidades de um país continental como o Brasil.

As discussões que mostram a importância do Triângulo Mineiro/Alto Paranaíba no cenário nacional, sobretudo como um importante entreposto de produtos agrícolas que abasteciam as principais cidades do Sudeste, foram fundamentais para delinear importantes eixos rodoviários e ferroviários na área por meio do Plano Nacional de Viação Rodoviário-1951. Tais discussões estão presentes nos documentos do Conselho Nacional de Transporte, relatadas pelo então Deputado Edison Passos (1952). Um exemplo é a Emenda número 86 de 1951, do mineiro Vasconcelos Costa que solicitava a ligação entre Monte Carmelo e Uberlândia.

Outra emenda importante refere-se ao político uberlandense Rondon Pacheco, governador do Estado de Minas Gerais, entre 1971 e 1975, que argumentava pela construção de uma rodovia entre Uberlândia, Monte Alegre de Minas, Avatinguara (atual Canápolis) e Ituiutaba, justificando a necessidade de um eixo rodoviário mais moderno. O parecer da referida emenda coloca que "realmente é de grande interesse o traçado sugerido, pois atravessa região de alto potencial econômico, como acentuou o nobre autor da emenda" (CONSELHO NACIONAL DE TRANSPORTES, 1952, p. 203 e 204).

Dessa forma, pode-se perceber a força econômica e política que se colocava no Triângulo Mineiro à época, diante da circulação econômica de cereais e grãos que abasteciam São Paulo e Rio de Janeiro. Essa emenda também indica como os atores políticos dessa mesorregião, em especial do Triângulo Mineiro, procuravam aliar seus interesses regionais com as estratégias nacionais de ocupação do interior do país, delineando os modernos sistemas rodoviários para a integração da área à economia nacional, assegurando a inserção da região através dos eixos mais modernos na rede rodoviária nacional.

Silveira (2003) argumenta que a grande vantagem da rede rodoviária foram os baixos investimentos estatais para a sua viabilização inicial, ou seja, os baixos custos de implantação se comparados às ferrovias, juntamente com a possibilidade da aquisição de veículos por parte da população e de segmentos logísticos. Além disso, o transporte rodoviário gerava maior possibilidade de acumulação de capital com um mercado variado em torno dessa rede viária. Ademais, era urgente a necessidade de integrar os mercados isolados em que a facilidade e 0 barateamento da construção do sistema rodoviário possibilitariam o projeto estratégico dessa 
integração territorial via mercado e reorientação da divisão territorial do trabalho, comandada pelo Sudeste do país.

A partir desse contexto, pode-se então afirmar que a preocupação do Governo Vargas, com relação ao desenvolvimento econômico, atingiu diretamente as infraestruturas de transportes, com a necessidade da fixação de sistemas viários que articulassem, segundo Anselmo (2000) a unidade nacional e garantissem a efetiva ocupação ao Oeste do território sob o comando do Estado Nacional, pautado na reprodução capitalista pelo vetor urbano industrial.

Em relação ao transporte rodoviário, na segunda metade do século $X X$, foram construídas várias rodovias federais, cujos projetos estavam diretamente alicerçados nos planos analisados, em virtude das novas estratégias adotadas em relação à entrada do capital estrangeiro no mercado brasileiro que colaboraram significativamente para o desenho do modelo de integração via sistemas rodoviários que se verificou no país. Dessa forma, as discussões dos planos viários desde o final do século XIX e a primeira metade do século XX, discutidos neste trabalho, foram basilares para a materialização dos Planos e eixos rodoviários durante a segunda metade do século XX. Em outras palavras, o período que se estende entre as décadas de 1950 e 1970 corresponde à instalação definitiva das estratégias debatidas e elaboradas desde a Primeira República. Efetivou-se a transferência da Capital Federal para o Planalto Central, intensificou-se o processo da integração do Oeste do território a partir do vetor urbano e industrial, e materializaram-se grandes investidas de construção de infraestrutura viária, com destaque para os sistemas rodoviários em detrimento do ferroviário, conforme indica a Figura 10.

Após o Governo de Vargas, já na segunda metade do século XX, foram implantadas diversas rodovias federais, cujos projetos estavam diretamente alicerçados na integração nacional e na transferência da Capital Federal para o interior do país. Um dos marcos que possibilitou tamanha instalação de infraestruturas consistiu no Governo de Juscelino Kubistchek e as novas estratégias adotadas em relação à entrada do capital estrangeiro - originados de empréstimos internacionais e da ação de multinacionais ligadas ao automobilismo - sobre o mercado brasileiro, o qual colaborou significativamente para o desenho do modelo de integração via redes rodoviárias que se verificou no país.

Através dos Planos Viários Nacionais, elaborados no Brasil desde a primeira metade do século XIX e na Era Vargas, o mote da modernização pela rede viária ganhou importância pela inserção das rodovias no país, diante do esvaziamento da ideia de integração que o limitado e desarticulado sistema ferroviário brasileiro possibilitou. Além disso, os avanços tecnológicos proporcionados durante o período pós-guerra, somados à necessidade da criação de um mercado interno que atendesse os produtos advindos da recente industrialização brasileira, mostrou ao país a necessidade de se constituir uma rede rodoviário integrado e eficiente para ordenar o espaço e potencializar a reprodução do capital.

Figura 10 - Evolução do sistema rodoviário pavimentado no Brasil entre 1890 a 1980 (em quilômetros).

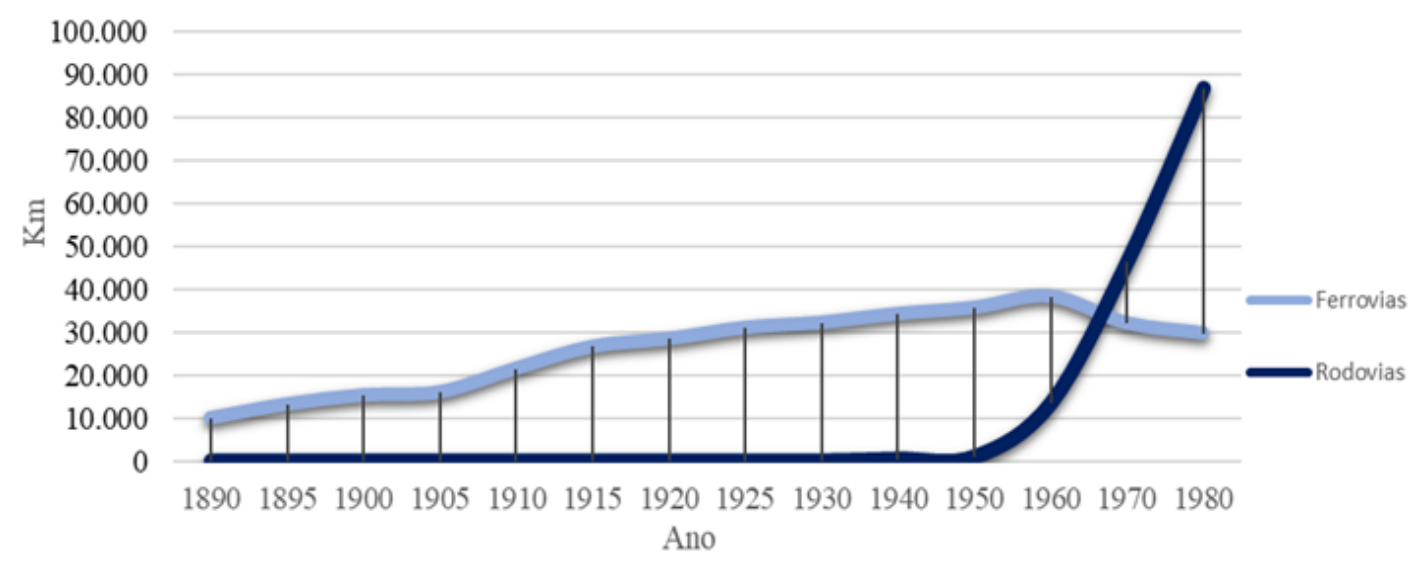

Fonte - SILVEIRA (2003); DNV-DNIT (2002). Organização - autores, 2017. 
Dever-se-ia assegurar condições mínimas à circulação interna de pessoas, mercadorias e possibilitar o acesso rápido e eficiente da produção nacional - concentrada em São Paulo destinada ao mercado interno e à exportação, tendo como pilar desse processo a modernização do país pela constante expansão do sistema rodoviário e do segmento logístico. Tal fato pode ser largamente constatado através da construção de Brasília no Planalto Central, que, dentre outros fatores, possibilitou a expansão da malha rodoviária ao interior do país, a expansão dos mercados de consumo e possibilidades de produção, e a organização e integração do território brasileiro tendo os sistemas rodoviários como elementos capitais nesse processo.

A construção de rodovias em direção ao Planalto Central redefiniu a situação geográfica da mesorregião do Triângulo Mineiro/Alto Paranaíba, sobretudo por firmar esta área como uma área estratégica de integração entre a principal região econômica - São Paulo - e a administração federal - Brasília, junto com expansão da agropecuária no Cerrado. Em outras palavras, a instalação da rede rodoviária a partir do fim da década de 1950, efetivou a configuração do Triângulo Mineiro/Alto Paranaíba numa importante situação geográfica de integração nacional, pelo qual os transportes foram os indutores principais da redefinição da produção material (na indústria, agricultura comercial e serviços) ampliando as possibilidades de produção de riqueza.

Como trabalhado por Guimarães (2010) e Cleps (2000), a construção de Brasília no Planalto Central - que passou a reorientar os fluxos econômicos para o interior do Brasil, bem como a industrialização centralizada no Centro-Sul - redefiniram o papel do Triângulo Mineiro/Alto Paranaíba na divisão inter-regional do trabalho. Assim, a partir da década de 1950, marcou-se uma nova etapa para a integração regional apoiada pelos novos agentes de modernização (rodovias).

No aspecto regional, este período, com certeza, representou um marco decisivo para a economia triangulina e para a própria estruturação da economia nacional. Ou seja, com a consolidação da meta-síntese do Plano de Metas de JK - a construção de Brasília - o espaço geográfico do Triângulo Mineiro passou, de uma vez por todas, a localizar-se estrategicamente entre a principal região econômica do país - São Paulo - e a administração central - Brasília (GUIMARÃES, 2010, p.121).

Portanto, durante a construção de Brasília (1957 - 1960) a dinamização da economia do Triângulo Mineiro/Alto Paranaíba foi percebida nos diversos setores econômicos, como por exemplo: insumos direcionados à construção civil, a fabricação de cimento, manilhas, telhas, até a prestação de serviços, que sofreu grandes impactos, alavancando a economia (GUIMARÃES, 2010). Martins (1998) também discute a dinâmica econômica na região durante a construção de Brasília, cujas transações entre Brasília e São Paulo passaram a ser articuladas por meio da mesorregião. Em outros termos, a evolução da infraestrutura na região através da construção de Brasília ocasionou a expansão e modernização dos transportes, das telecomunicações e da energia na região, identificados como elementos decisivos para sua integração produtiva e comercial e na estruturação do segmento logístico.

Destarte, é a partir de questões históricas e geográficas que a mesorregião do Triângulo Mineiro/Alto Paranaíba é colocada em evidência diante do projeto da integração nacional, favorecendo o desenvolvimento de atividades logísticas e de serviços, sobretudo em Uberlândia, redefinindo o espaço num contexto logístico. Nessa mesorregião materializou-se um dos maiores nós viários do Centro-Sul do Brasil (Figura 11), favorecendo a expansão do capital, transformações e crescimento urbano acelerado e atividades logísticas, formando um decisivo corredor logístico e de comunicação nessa região que está diretamente estruturada diante das estratégias de relevância nacional potencializadas para o aproveitamento das classes dominantes locais a fim de atrair investimentos e desenvolver suas economias locais. 
Figura 11 - Articulação viária na Mesorregião do Triângulo Mineiro/Alto Paranaíba, 2016.

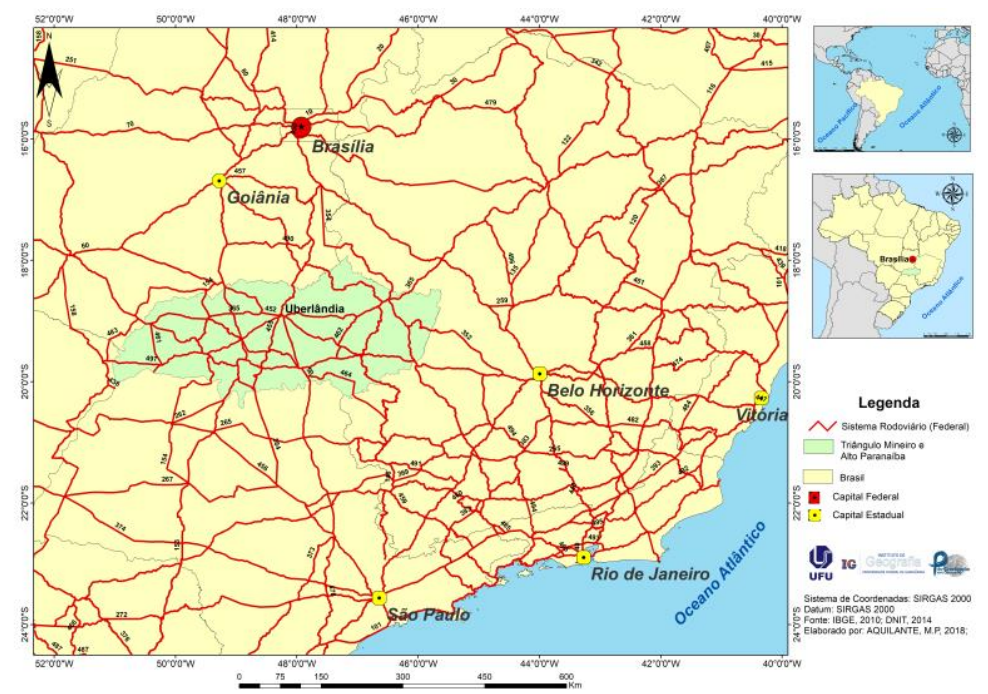

Fonte - IBGE (2010); DNIT (2014). Organização - autores, 2017.

Dessa forma, a relação entre o desenvolvimento do capital comercial com a dinamização e polarização dos núcleos urbanos, bem como a localização desses centros de acumulação do capital comercial em tais núcleos, indicam diretamente condições privilegiadas de infraestrutura logística de integração econômica que o Triângulo Mineiro/Alto Paranaíba exerce no cenário nacional, correspondendo uma área geoestratégica diante da integração nacional.

\section{CONSIDERAÇÕES FINAIS}

A partir da análise desenvolvida neste trabalho é possível concluir que os planos viários projetados e/ou implantados entre 1874 e 1951 foram basais para a compreensão dos planos viários da segunda metade do século XX. É nesse período que de fato foram construídas as principais obras viárias no território nacional, com a efetivação do processo de integração nacional, propiciado pela instalação de Brasília e a necessidade de eixos viários engendrando fluxos de pessoas, capitais e serviços ao longo do território.

As opções decisivas entre planos que articulavam as três modalidades de transporte rodoviário, ferroviário e hidroviário - e aqueles que criaram planos nacionais independentes para as três modalidades demonstram opções estratégicas que tiveram papel decisivo sobre a economia como um todo e a reconfiguração do território. Este trabalho traz esse debate à luz de modo a auxiliar na compreensão da opção pelo rodoviarismo a partir dos anos de 1950, num ordenamento do território de explícita articulação entre as novas opções industriais calcadas no capital estrangeiro em conjunto com o capital privado nacional e estatal e o estímulo ao consumo.

A mesorregião do Triângulo Mineiro/Alto Paranaíba foi servida por uma série de vias que lhe proporcionaram a condição estratégica em um dos maiores nós viários do Centro-Sul do Brasil favorecendo a reprodução do capital, transformações e crescimento urbano acelerado e atividades logísticas. Tais características engendraram um decisivo corredor logístico e de comunicação nessa região, a partir dos anos de 1970, que está diretamente estruturado diante da geoestratégica posição geográfica de relevância nacional. A moderna infraestrutura nessas áreas (transportes rodoviários, energia, investimentos diretos do Estado, investimentos internacionais e qualificação de mão de obra, como a instalação de universidades na região) transformou radicalmente a situação geográfica, promovendo a efetiva modernização e integração nacional. E foi justamente a malha rodoviária densa e eficiente que se estruturou como um dos elementos fundamentais à implantação das modernizações por meio da logística contemporânea e sua articulação com a lógica global na região. Tal processo torna-se mais 
evidente com a fixação e instalação de centros logísticos e de distribuição que modernizam e atraem novos fluxos.

Ademais, para além das iniciativas estatais que fluíram desde o século XIX, este trabalho demonstra que as classes dominantes locais foram extremamente importantes no sentido de aproveitar oportunidades e direcioná-las para o atendimento de seus interesses. Este aspecto particular do jogo político que articula local, regional e nacional é muito interessante para a compreensão da dinâmica territorial instalada, sobretudo da disputa entre os centros regionais da região. As elites de Uberlândia e Uberaba, por exemplo, aproveitaram-se, cada uma à sua maneira, da localização estratégica para atrair investimentos e desenvolver suas economias locais.

\section{AGRADECIMENTOS}

Agradecemos ao apoio da Fundação de Amparo à Pesquisa do Estado de Minas Gerais (FAPEMIG) e da Universidade Federal de Uberlândia em parceria com o Conselho Regional de Nord-Pas-de-Calais juntamente a UFR de Géographie et Aménagement da Université de Lille 1 para a realização do Projeto FAPEMIG/Conseil Régional "Wealth Through Sharing - Riquezas Compartilhadas".

\section{REFERÊNCIAS}

ANSELMO, Rita de Cássia Martins de Souza. Geografia e geopolítica na formação nacional brasileira: Everardo Adolpho Backheuser. 2000. Tese (Doutorado em Geografia Humana) Universidade Estadual Paulista Júlio de Mesquita Filho, Rio Claro, 2000.

ANSELMO, Rita de Cássia Martins de Souza; BRAY, Carlos Silva. Geografia e geopolítica na formação nacional brasileira: Everardo Adolpho Backheuser. GERALDI, Lúcia Helena de Oliveira; MENDES, landara Alves (Orgs.). In: Do Natural, do Social e de suas Interações: visões geográficas. Rio Claro: UNESP, 2002.

BRANDAO, Carlos. Território e Desenvolvimento: as múltiplas escalas entre o local e o global. São Paulo: Editora da Unicamp, 2009.

CAVALCANTI, Flavio R. Trens, Ferrovias e Ferreomodelismo. 2011. Disponível em: <http://vfco.brazilia.jor.br/centro-oeste/site/sobre.o.site.Centro-Oeste.shtml>. Acesso em: 31 mai. 2016.

CLEPS, Geisa Daise. Gumiero. A origem e o desenvolvimento do comércio atacadista em Uberlândia (MG). In: Sociedade \& Natureza, Uberlândia, ano 12, n.23, p.5-46, jan. /jun. 2000.

COIMBRA, Créso. Visão Histórica e Análise Conceitual dos Transportes no Brasil. Rio de Janeiro, CEDOP do Ministério dos Transportes, 1974. 364p.

CONSELHO NACIONAL DE TRANSPORTES - BRASIL. Plano Nacional de Viação e Conselho Nacional dos Transportes. Departamento de Imprensa Nacional. Rio de Janeiro, 1952. 331p.

FONSECA, Pedro. D. Vargas: capitalismo em construção. Brasiliense: São Paulo, 1999.

GALVAO, Olímpio J. de Arroxelas. Desenvolvimento dos transportes e integração regional no Brasil: uma perspectiva histórica. In: Revista Planejamento e Políticas Públicas (UFPE), no 13, junho, 1996.

GUIMARAES, Eduardo Nunes. Formação e Desenvolvimento Econômico do Triângulo Mineiro: Integração Nacional e Consolidação Regional. Uberlândia: EDUFU, 2010. 254 p. https://doi.org/10.14393/EDUFU-978-85-7078-249-6 
MACHADO, Lia Osório. Origens do pensamento geográfico no Brasil: meio tropical, espaços vazios e a idéia de ordem (1870-1930). In: CASTRO, Iná Elias; GOMES, Paulo César da Costa; CORRÊA, Roberto Lobato (Orgs.). Geografia: Conceitos e Temas. 8.ed. Rio de Janeiro: Bertrand Brasil, 2006. p.309-352.

MARTINS, Humberto E. de Paula. Formação e desenvolvimento socioeconômico do Triângulo Mineiro. In: Varia História, Belo Horizonte, ํo19, 1998, p.164-182

MINISTÉRIO DOS TRANSPORTES. Transportes no Brasil: Síntese Histórica. 2014. Disponível em: <http://www.transportes.gov.br/conteudo/54-institucional/136-transportes-no-brasil-sintesehistorica.html>. Acesso em: 31 mai. 2016.

MORAES, A.C.R. Bases da formação territorial no Brasil. Ed. Hucitec, 2000. 432p. https://doi.org/10.7147/GEO2.1145

MONBEIG, Pierre. Pioneiros e fazendeiros de São Paulo. Tradução Ary França e Raul de Andrade e Silva. São Paulo: Hucitec/Polis, 1984.

NIGRIELLO, A. Planos nacionais de viação. In: Planejamento de Estruturas Urbanas e Regionais II. Apresentação de trabalho, conferência ou palestra. Universidade de São Paulo, SP, 2009.

PENHA, Eli Alves. A criação do IBGE no contexto da centralização política do Estado Novo. Rio de Janeiro: IBGE, CDDI, 1993. (Documentos para Disseminação. Memória Institucional, 4). Disponível em: <http://biblioteca.ibge.gov.br/visualizacao/monografias/GEBIS\%20-

\%20RJ/ColecaoMemorialnstitucional/04-A\%20Criacao\%20do\%20IBGE.pdf>. Acesso em: 06 mar de 2019.

SANTOS, R. A. Planos nacionais de viação: A Integração Nacional Através dos Caminhos. In: Planejamento de Estruturas Urbanas e Regionais II. Apresentação de trabalho, conferência ou palestra. Universidade de São Paulo, SP, 2008

SILVEIRA, Márcio Rogério. A importância geoeconômica das estradas de ferro no Brasil. Tese (doutorado). - Universidade Estadual Paulista, Faculdade de Ciências e Tecnologia Presidente Prudente: [s.n.], 2003. $454 \mathrm{f}$.

SILVEIRA. Maria Laura. Uma situação Geográfica: do método à metodologia. In: Revista Território, ano IV, nt1 6, jan./jun. 1999.

SOUZA NETO, M. F. Planos para o Império. Os planos de viação do Segundo Reinado (18691889), Alameda, São Paulo, 2012.

VENCOVSKY, Vitor Pires. Ferrovia e logística do agronegócio globalizado: avaliação das políticas públicas e privadas do sistema ferroviário brasileiro. 2011.172 p. Tese (doutorado) - Universidade Estadual de Campinas, Instituto de Geociências, Campinas, SP.

Recebido em: 12/11/2017

Aceito para publicação em: 24/03/2019 